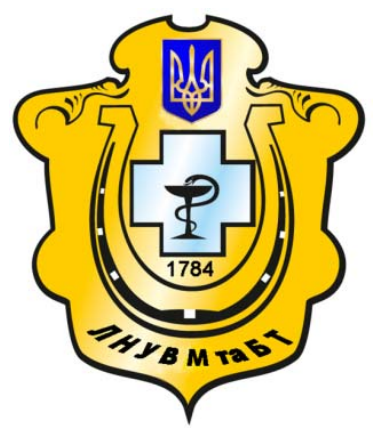

Науковий вісник Львівського національного університету ветеринарної медицини та біотехнологій імені С.3. Гжицького

Scientific Messenger of Lviv National University of Veterinary Medicine and Biotechnologies named after S.Z. Gzhytskyj

doi:10.15421/nvlvet6603

ISSN 2413-5550 print

ISSN $2518-1327$ online

$\underline{\text { http://nvlvet.com.ua/ }}$

\title{
УДК 619:616.381-002:636.8
}

\section{Макроскопічні зміни за інфекційного перитоніту котів}

\author{
Б.В. Борисевич, В.В. Лісова, М.С. Криштоп, О.В. Пятецька \\ lisovav@ukr.net
}

Національний університет біоресурсів і природокористування України, вул. Героїв Оборони, 11, м. Київ, 03041, Україна

\begin{abstract}
Проведено патологоанатомічне дослідження 6 трупів котів, які загинули від інфекційного перитоніту (FIP) з метою виявлення макроскопічних змін в уражених органах і тканинах. Встановлено, щяо при проведенні патологоанатомічного розтину трупів котів, що загинули від FIP, в частині випадків одночасно виявляються макроскопічні зміни, характерні як для ексудативної, так і для проліферативної (сухої) форм хвороби. Такі зміни характерні для змішаної форми хвороби.

При змішаній формі хвороби в черевній порожнині всіх досліджених нами котів знаходили прозору, густу, яскраво жовтого кольору желеподібну речовину. Оскільки за прижиттєвої пункиії черевної порожнини в ній виявляли прозору, густу, яскраво жовтого кольору рідину з високим вмістом білку та наявністю в ній фібрину, нами було зроблено висновок, щцо присутній в иій рідині білок після смерті тварини згортається, внаслідок чого густа рідина стає гелем, втрачаючи текучість. За асииту будь-якої іншої етіології також відбувається накопичення рідини, але на відміну від FIP вона майже без кольору, не густої консистениії, оскільки в ній мало білку та відсутній фібрин, щэо надає ексудату властивостей студня.

Макроскопічні ознаки за ексудативної форми FIP не відрізнялися від описаних в літературі.

Ключові слова: коти, коронавірусна інфекиія, інфекційний перитоніт, ексудативна форма хвороби, змішана форма хвороби, діагностика, патологоанатомічний розтин, макроскопічні зміни, ексудат, асцит, печінка, илунково-кишковий тракт, нирки.
\end{abstract}

\section{Макроскопические изменения у котов при инфекционном перитоните}

\author{
Б.В. Борисевич, В.В. Лисовая, М.С. Криштоп, О.В. Пятецкая \\ lisovav@ukr.net
}

Национальный университет биоресурсов и природопользования Украины, ул. Героев Обороны, 11, Киев, 03041, Украина

\begin{abstract}
Проведено патологоанатомическое исследование 6 трупов котов, которые пали от инфекционного перитонита (FIP) с целью выявления макроскопических изменений в поражённых органах и тканях. Установлено, что при проведении патологоанатомического вскрытия трупов котов, павших от FIP, в части случаев одновременно выявляются макроскопические изменения, характерные как для экссудативной, так и для пролиферативной (сухой) форм болезни. Такие изменения характерны для смешанной формы болезни. При смешанной форме болезни в брюшной полости всех исследованных нами котов находили прозрачное, густое, ярко желтого извета желеобразное вещество. Поскольку при прижизненной пункции брюшной полости в ней выявляли прозрачную, густую, ярко желтого извета жидкость с высоким содержанием белка и наличием в ней фибрина, нами был сделано вывод, что присутствующий в этой жидкости белок после смерти животного сворачивается, вследствие чего густая жидкость становится гелем, утрачивая текучесть. При асиите любой другой этиологии также накапливается жидкость, но в отличие от FIP она почти бесиветная, не густой консистенции, поскольку в ней мало белка и отсутствует фибрин, придающие экссудату свойства желе. Макроскопические признаки при экссудативной форме FIP не отличались от описанных в литературе.

Ключевые слова: коты, коронавирусная инфекиия, инфекционный перитонит, экссудативная форма болезни, смешанная форма болезни, диагностика, патологоанатомическое вскрытие, макроскопические изменения, экссудат, асиит, печень, желудочно-кишечный тракт, почки.
\end{abstract}

\section{Citation:}

Borysevych, B.V., Lisova, V.V., Kryshtop, M.S., Pyatezka, O.V. (2016). Gross changes at the feline infectious peritonitis. Scientific Messenger LNUVMBT named after S.Z. Gzhytskyj, 18, 2(66), 13-15. 


\title{
Gross changes at the feline infectious peritonitis
}

\author{
B.V. Borysevych, V.V. Lisova, M.S. Kryshtop, O.V. Pyatezka \\ lisovav@ukr.net \\ National University of life and environmental sciences of Ukraine, \\ Heroyiv Oborony Str., 11, Kyiv, 03041, Ukraine
}

Conducted necropsy of 6 dead cats who died from feline infectious peritonitis (FIP) with the aim of identifying the gross changes in the affected organs and tissues. It is established that at the necropsy of cats that died from FIP, in some cases simultaneously revealed macroscopic changes, is characterized as an exudative and proliferative (dry) forms of the disease. Such changes are characteristic for mixed forms of the diseases.

At the mixed form of the disease in the abdominal cavity of all examined cats were found transparent, thick, bright yellow jellylike substance. Since the lifetime puncture of the abdominal cavity it revealed a transparent, thick, bright yellow fluid with high protein content and the presence of fibrin, we have concluded that present in this liquid protein after the death of the animal is coagulated, resulting in a thick liquid becomes a gel and loses its fluidity.

In the ascites of any other etiology also accumulate fluid, but unlike FIP, it is almost colorless, thick consistency, because it is containing a little protein and no containing fibrin, giving the fluid properties of jelly.

Gross changes of exudative FIP did not differ from those described in the literature.

Key words: cats, coronavirus infection, infectious peritonitis, exudative form of the disease, mixed form of the disease, diagnosis, necropsy, gross changes, exudate, ascites, liver, gastrointestinal tract, kidneys.

\section{Вступ}

Особливою проблемою інфекційної патологї̈ в котів є вірусні інфекції, в тому числі й інфекційний перитоніт (FIP). Це підгостра чи хронічна вірусна хвороба диких і домашніх котів, що викликається одним 3 котячих коронавірусів, який реплікується у макрофагах. Хвороба проявляється у трьох формах ексудативній (вологій), проліферативній (сухій), а в $75 \%$ котів у скритій (безсимптомній) формі (Starchenkov, 2001; Remsy and Tennat, 2005). Всі автори вважають FIP досить складним для діагностики станом внаслідок наявності багатьох захворювань зі схожими ознаками. Остаточний діагноз можливо встановити лише посмертно гістологічним і імуноцитохімічним методами, а прижиттєво - за результатами бionciï (Starchenkov, 2001; Remsy and Tennat, 2005; Addie, 2009).

Патогенез і патологоанатомічні зміни за інфекційного перитоніту котів залишаються недостатньо вивченими аспектами цієї хвороби. За даними (Reshetnicova, 2006) при розтині тварин з ексудативною формою FIP, найбільш виразною ознакою є наявність у черевній порожнині великої кількості жовтої або брудно-сірої рідини, як правило прозорої, але можуть бути присутніми пластівці фібрину, рідина в плевральній порожнині ідентична. На поверхні серозних оболонок часто сірувато-білі відкладення фібрину, а сальник темний, потовщений і зернистий. При сухій формі гранульоматозні зміни у вигляді білих вогнищ добре видно на зрізах внутрішніх органів.

Мета $i$ завдання дослідження. Виходячи з вищесказаного ми поставили собі за мету вивчити патологоанатомічні (макроскопічні) зміни в органах і тканинах у котів, які загинули від FIP.

\section{Матеріал і методи досліджень}

Діагноз на FIP встановлювали комплексно з урахуванням анамнезу, клінічних ознак і результатів лабораторних досліджень (лабораторія «Бальд», м. Київ). Патологоанатомічний розтин 6 трупів котів, що загинули внаслідок FIP, проводили методом часткової евісцерації в загальноприйнятій послідовності (Zon et al., 2009).

\section{Результати та їх обговорення}

При проведенні патологоанатомічного розтину в двох котів реєстрували ексудативну форму хвороби, а в чотирьох - поєднання ознак ексудативної й сухої форм хвороби (тобто змішану форму).

При змішаній формі хвороби під час зовнішнього огляду трупів відмічали виразну жовтяничність шкіри, підшкірної клітковини, видимих слизових оболонок, склери очей, серозно-гнійні витікання 3 носових отворів, серозно-гнійний кон'юнктивіт. Кровоносні судини підшкірної клітковини розширені, переповнені кров'ю. Усі соматичні лімфатичні вузли збільшені, жовтяничні, на розрізі паренхіма соковита, однорідна жовтянична, вибухає за межі капсули. У органах грудної порожнини крім жовтяничності реберної й легеневої плеври та розширення й переповнення іiї кровоносних судин, інші видимі зміни не виявляли.

У черевній порожнині всіх досліджених нами трупів котів знаходили біля 500 мл прозорої, густої, яскраво жовтого кольору желеподібної речовини (478 \pm 21 мл). Оскільки за даними анамнезу при прижиттєвій пункції черевної порожнини в ній виявляли прозору, густу, яскраво жовтого кольору рідину з високим вмістом білку та наявністю в ній фібрину (за даними лабораторних досліджень), нами будо зроблено висновок, що присутній в цій рідині білок після смерті тварини згортається, внаслідок чого густа рідина стає гелем, втрачаючи текучість.

За асциту будь-якої іншої етіології також відбувається накопичення в черевній порожнині рідини, але на відміну від рідини, яка була нами виявлена в черевній порожнині котів, які загинули від FIP, рідина при асциті іншої етіології майже без кольору, не густої 
консистенції, оскільки в ній мало білку та відсутній фібрин, що надає ексудату властивостей студня. Тому на нашу думку рідина в черевній порожнині котів зі змішаною формою FIP внаслідок їі досить специфічних властивостей має важливе діагностичне значення.

Виразні макроскопічні зміни реєструвалися в печінці, кишечнику, кишкових лімфовузлах, нирках. У шлунку, селезінці, сечовому міхурі видимі зміни були відсутні, за винятком змін на поверхні їх серозної оболонки. Діафрагмальна поверхня печінки була вкрита досить товстою, пухкою біло-жовтого кольору плівкою фібрину, яка на деяких ділянках зросталася 3 капсулою печінки. Під фібринозними нашаруваннями майже вся площа печінки була всіяна дрібними округлої форми вузликами білувато-сірого кольору, які локалізувались в ділянці капсули органу. На вісцеральній поверхні печінки прошарок фібрину був дещо меншим, але на його поверхні спостерігали окремі білуваті, розміром з горошину вузлики, які поширювались вглиб на капсулу органу та субкапсулярну паренхіму. На розрізі такі гранульоматозні вогнища мали характер гнійного ексудату, що в деяких літературних джерелах було описано, як піогрануломатоз поверхні печінки.

Серозна оболонка тонкої й товстої кишок також була більш-менш однорідно вкрита білими вузликами округлої чи овальної форми. Кишкові лімфатичні вузли збільшені, щільної, пружної консистенції, жовтяничні. На розрізі паренхіма соковита, вибухає за межі капсули. Кровоносні судини брижі розширені, переповнені кров'ю, чітко контуровані. Зміни слизових оболонок травного тракту характеризувались макроскопічними ознаками, характерними для катарального ентериту, який охоплював кишечник від початкової частини дванадцятипалої кишки до кінцевої частини ободової кишки. На капсулі нирок спостерігали поодинокі вузликові ураження ідентичні таким на капсулі печінки й серозній оболонці кишечника.

Слід підкреслити, що на відміну від описаної в літературних джерелах патологоанатомічної картини при типовій гранульоматозній формі хвороби (Reshetnicova, 2006) гранульоматозні зміни у вигляді білих вогнищ в товщі внутрішніх органів в жодному випадку нами не були знайдені. Вони мали виключно поверхневе розташування (ділянка капсули органу та фібринозні накладання на зовнішній поверхні органів).

За ексудативної форми хвороби жовтяничність слизових і серозних оболонок нами встановлена не була. У черевній порожнині всіх котів з цією формою FIP знаходили прозору, відносно густу, яскраво жовтого кольору рідину, що відповідає описаним при цій хворобі змінам (Addie, 2009). Проте, в грудній поро- жнині і в осерді одного кота було знайдено речовину, яка мала такі ж характеристики, як і речовина в черевній порожнині котів при змішаній формі хвороби.

\section{Висновки}

1. При проведенні патологоанатомічного розтину котів, що загинули від FIP, в частині випадків одночасно виявляються макроскопічні зміни, характерні як для ексудативної, так і проліферативної (сухої) форм хвороби. Такі зміни реєструються за змішаної форми хвороби.

2. При змішаній формі хвороби в черевній порожнині виявлено яскраво жовтого кольору желеподібну речовину, що має важливе діагностичне значення. За асциту будь-якої іншої етіології також відбувається накопичення рідини, але на відміну від FIP вона майже без кольору, не густої консистенції, оскільки в ній мало білку та відсутній фібрин, що надає ексудату властивостей студня.

3. Макросокпічні ознаки при ексудативній формі FIP не відрізнялися від описаних у літературі.

Перспективи подальших досліджень полягають у детальному дослідженні патологічного матеріалу 3 використанням гістологічних методів 3 метою з'ясування мікроструктурних змін в уражених органах і тканинах.

\section{Бібліографічні посилання}

Remsy, Ya., Tennat, B. (2005). Bolezny koshek [Diseases of cats]. Moskva: OOO «Acvarium-print», 282-283 (in Russian).

Remsy, Ya., Tennat, B. (2005). Infekcyonniye bolezny sobak i koshek: practicheskoye rucovodstvo [Infectious diseases of dogs and cats]. Moskva : OOO «Acvarium-print» (in Russian).

Zon, G.A., Skripka, M.V., Ivanovska, L.B. (2009). Patologoanatomychnyi rostin tvarin [Necropsy of animals]. Donezk: PP Glazunov R.O. (in Ukrainian).

Reshetnicova, N.G. (2006). Coronavirusnaya infecziya koshek. Virusniy peritonit koshek [Coronavirus infection of cats. Feline infectious peritonitis]. Available at : http://www.kubanvet.ru/2_20063.html (in Ukrainian).

Starchenkov, S.V. (2001). Zarazniye bolezny sobak I koshek [Infectious diseases of dogs and cats]. SanktPeterburg: OOO «SPS» (in Russian).

Addie, D. (2009). Feline infectious peritonitis. ABCD guidelines on prevention and management. Journal of Feline Medicine and Surgery, 11 (7), 594-604.

Стаття надійшла до редакції 28.09.2016 